\title{
MULCH APPLICATION ON BARLEY GRAIN YIELD AND PHYSICOCHEMICAL PROPERTIES OF SOIL IN NEGELE ARSI DISTRICT, CENTRAL, ETHIOPIA
}

\author{
Fekadu Dule ${ }^{1 *}$ \\ I* Ethiopian Environment and Forest Research Institute, Hawasa Environment and Forest Research \\ center (HEFRC), Hawasa, Ethiopia.
}

Zebene Asfew ${ }^{2}$

${ }^{2}$ Hawasa University, Wondo Genet College of Forestry and Natural Resources, WondoGenet, Ethiopia.

Article DOI: $\underline{\text { https://doi.org/10.36713/epra6311 }}$

\begin{abstract}
There is uncertainty about the type of mulch to use to reduce soil nutrient depletion and water loss and at the same time enhance crop yield that will also be influenced by the materials available locally for use and their management. The objective of this study was to investigate the effect of mulch application on barley grain yield and physicochemical properties of soil in Negele Arsi district, Central, Ethiopia. Experimental plots were laid on farmers fields' in randomized complete block design by taking farmers field as a replication. Five farms of each with a currently mulched plot, a year ago mulched plot with perennial mulch and conventional fields as control (15plots of 10m in width and $20 \mathrm{~m}$ in length in general) were selected for the establishment of the experiment. Subplots of $1 \mathrm{mx}$ Im at each corner and a center of each main plot were used for taking barley grain yield and soil data. A total of 30 soil samples collected from two depth layers: 0-20 and 20-40cm were air-dried and passed through a $2 \mathrm{~mm}$ sieve to remove roots, and large organic residues. Soil organic carbon concentration in the soil samples was determined by Walkley and Black method. The soil data were subjected to a two-way ANOVA analysis using the general linear model Procedures of $S A S$. The pairwise comparison method was also used to assess the mean difference of the treatment types and depth levels depending on soil properties. The average barley grain yield obtained from plots mulched with perennial mulch in 2018 (1.52 $\pm 0.209 \mathrm{~kg})$ was higher than plots mulched in 2017 (1.48 $\pm 0.135 \mathrm{~kg}$ ) and conventional farmland plots

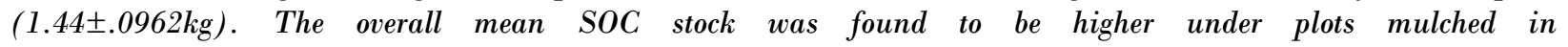

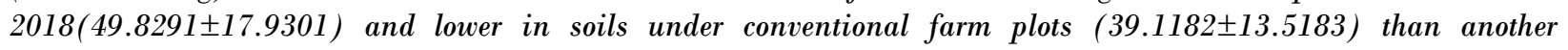
treatment type. The highest overall mean of soil carbon stock under plots mulched in 2018 indicates that perennial mulch might be the remedy for replenishing the declining soil fertility on conventional farmlands and to increase barley grain yield on a sustainable basis.
\end{abstract}

KEYWORDS: conventional farm, grain yield, perennial mulch, soil fertility 


\section{SJIF Impact Factor 2021: 7.13| ISI I.F.Value:1.241| Journal DOI: 10.36713/epra2016 \\ ISSN: 2455-7838(Online) \\ EPRA International Journal of Research and Development (IJRD) \\ Volume: 6 | Issue: 2 | February 2021 \\ - Peer Reviewed Journal}

\section{INTRODUCTION}

The choice of selection of an appropriate mulching material depends on the local climate, costeffectiveness, and crop feasibility (Wang et al., 2015). Mulching is a very useful practice in rain fed areas for conserving nutrients in the soil profile (Sharma et al., 2010). Boosting the number of nutrients retained in the soil through mulching and limiting nutrient leaching has positive effects on crop yields (Silver town et al., 2006). The research conducted by McMillen. (2013) showed that the addition of mulching materials such as grass clippings, wheat straw, and debris of leaves of 5$10 \mathrm{~cm}$ depth improved soil moisture by $10 \%$ compared to the bare soil. The biological and chemical properties of soils play an essential role in the regulation of organic matter decomposition, carbon sequestration, and nutrient mineralization that are crucial for soil health (Kader et al., 2017). However, it is still unknown under which conditions and to what extent changes in soil organic matter contents are governed Steinmetz et al.(2016), and furthermore, as reported by Chapman et al. (2012) having such kind of knowledge is important for estimating soil carbon stock in intensive agricultural practices in which most of the mulching materials are removed at harvest.

Mulching with vegetative materials is a highly beneficial and widely-investigated agro-technique in rain-fed areas but the adoption of this practice has been constrained due to the non-availability of mulch biomass locally (Sharma et al., 2010). Live mulching with fast-growing annual green manure legumes like sun hemp (Crotalaria juncea) or pruning of Leucaena leucocephala grown as hedgerows can be done for conserving moisture and nutrient cycling in maize wheat cropping system (Sharma et al.,2010). Crop residues are preferentially used to feed domestic ruminants (De Ridder et al., 2004; Giller et al., 2009), so woody vegetation can provide an in situ source of leaf and branch biomass for soil amendment (Dossa et al., 2013). Moreover, many studies have confirmed that various types of living mulch perform differently in different soil systems (Qian et al., 2015). Therefore, more research is needed to identify the benefits of mulching with different types of soil systems (Zhong et al., 2018). There is a possibility of biomass production and nutrient cycling through live mulching of in-situ grown annual legumes as well as perennial leguminous trees and shrubs as hedgerows along the field bunds (Sharma et al., 2010). There is still uncertainty about the type of mulch to use to reduce soil nutrient depletion and water loss, and at the same time maintain or enhance crop yield that will also be influenced by soil type, rainfall intensity, and the materials available locally for use and their management (Manu et al.,
2018). The mechanisms by which woody amendments may provide benefits to soils and crops remain poorly understood, and no effective agronomic recommendations on the use of leaf and branch material currently exist in the South West Africa context (Félix et al., 2018). Rosa abyssinica is one of the mulching materials used in Meraro Hawilo kebele. Kebele is the smallest administrative unit in Ethiopia. It is categorized under a family of Rosacea, its English name is Abyssinian rose and in Ethiopia, it is known as Kega in Amharic language and Gora in Afan Oromo (Bekele, 2007). As Bekele. (2007) reported Rosa Abyssinica is ecologically found in Ethiopia in upland dry evergreen forests and margins or clearings of forests as well as in bush land and dry grasslands. So far, so many researches were conducted on different mulching materials under various agro-climatic conditions. But the scientific research that investigates the effect of perennial mulch application on barley grain yield and physicochemical properties of soil in Negele Arsi district, Central, Ethiopia was not done yet. Thus, it is imperative to investigate the effect of mulch application on barley grain yield and physicochemical properties of soil in Negele Arsi district, Central, Ethiopia.

\section{MATERIALS AND METHODS 2.1. Description of the study area}

The study was conducted in Meraro Hawilo Kebele, Negele Arsi district of West Arsi Zone, Oromia Regional State of Ethiopia. Meraro Hawilo is one of the 36 rural kebeles' of Negele Arsi district found at $32 \mathrm{~km}$ distance in the southeast direction of the district's town Negele (Fig 1).

The average annual temperature of the study area varies from $10-27{ }^{\circ} \mathrm{C}$, while rainfall varies between $500-1150 \mathrm{~mm}$. The area has four distinct seasons including the dry season (December to February), the short rainy season (March to May), the main rainy season (June to August), and the autumn season (September to November) (ORS, 2004, unpublished). Meraro Hawilo is one of the kebeles' found in highland agro ecology. Gara Duro which is the highest peak (3095m) in the district is found in Meraro Hawilo kebele (ORS, 2004, unpublished).

Barley is a staple food crop in Meraro Hawilo kebele. Maize, Bean, Wheat, and Enset are also widely grown crops in the kebele.

\subsection{Research design}

Experimental plots were laid on farmers fields' in randomized complete block design by taking farmers field as a replication. Three treatments such as currently mulched plots (in 2018 physical year), a year ago mulch plot (2017 physical year), and conventional 


\section{SJIF Impact Factor 2021: 7.13| ISI I.F.Value:1.241| Journal DOI: 10.36713/epra2016 \\ ISSN: 2455-7838(Online) \\ EPRA International Journal of Research and Development (IJRD) \\ Volume: 6 | Issue: 2 | February 2021 \\ - Peer Reviewed Journal}

farm plots as control were established on farmers fields' in five-block; in this case number of block and treatments was five(5). Five farms of each with a currently mulched plot, a year ago mulched plot with perennial mulch and conventional fields as control (15plots of $10 \mathrm{~m}$ in width and $20 \mathrm{~m}$ in length in general) were selected for the establishment of the experiment on the farmers' field at Meraro Hawilo kebele where mulching with Rosa abyssinica is practiced and known in a summer season. The current mulch plot is a virgin land occupied by Rosa abyssinica stand but recently brought under conservation agriculture while a year ago mulch plot is a virgin land brought under conservation agriculture in the past year. Conventional farmland is the land that was under conservation agriculture but over time changed to intensive agriculture.

Subplots of $1 \mathrm{mx} 1 \mathrm{~m}$ at each corner and a center of each main plot $(10 \times 20 \mathrm{~m})$ were used for taking barley grain yield and soil data (Fig 2). Crop in each subplot was harvested independently and then mixed together for threshing to get one representative Barley grain yield sample for each plot. Soil samples were taken at the depth of $0-20 \mathrm{~cm}$ and $20-40 \mathrm{~cm}$ (Fig 2) by using a soil core sampler of size $20 \mathrm{~cm}$ height and $3 \mathrm{~cm}$ in radius. The second layer soil sample was taken in the opposite direction of the first soil layer in order to avoid the effect of leaching of soil nutrients on the second layer. A soil sample was collected after barley crop harvesting completed for analyzing soil $\mathrm{pH}$, soil textural class, $\mathrm{OC} \%$, soil organic carbon stock, available $\mathrm{K}, \mathrm{P}_{\mathrm{av}}$, and $\mathrm{MC} \%$. For bulk density, a soil sample was collected independently by the same procedure followed for other soil properties and Corresponding layers, from the five small subplots within a plot, were mixed together to form one composite soil sample for each plot independently and $500 \mathrm{gm}$ soil from each plot was brought to Wondo Genet College of Forestry and Natural resource soil laboratory for analysis.

After gathering information from key informants on the total number of farmers who practice mulching with Rosa abyssinica in the village and characterization of each farm according to its previous history, a random sampling method was used for the selection of five farms to be used for laying out experimental plots. Experimental site selection criteria took into consideration factors such as availability of the practice of mulching with Rosa abyssinica by farmers in nearby places to each other to minimize the variation of soil characteristics that may arise from topographic difference, land aspect, altitude, site history, and others so as to minimize variation among the treatments and it was guided by the information obtained from key informants and personal observation at the site.

A $2 \mathrm{~kg}$ barley seed was sown on each of five current mulch plots, conventional farm plots, and a year ago mulched plots. Six procedures listed below(1-6) that are familiar among the farmers for mulching with Rosa abyssinica were followed for establishing experimental plots on the farmers' field: (1) Selection of pure Barley seed variety,(2)Calling for Self-help system among farmers ("Dabo"), (3)Lightly broadcasting of barley seeds by hand over Rosa abyssinica stand, as a single seed can bear tiller and cover the whole area,(4) Cutting and distributing of Rosa abyssinica over the sown seed; cutting of the branches of larger trees also carried out to minimize shade effect. Mulching with fresh Rosa abyssinica was conducted at this stage, (5) Chopping of Rosa abyssinica into pieces so as to improve germination of Barley seed and (6) Hand hoeing over bare plots so as to cover the seed and minimize seed eaten by birds was the steps followed in general for the establishment of the experiment.

\subsection{Laboratory analysis}

A total of 30 soil samples were air-dried and passed through a $2 \mathrm{~mm}$ sieve to remove roots, and large organic residues. Soil bulk density was determined by the core method and Soil particle size analysis (soil texture) was done by the hydrometer method (Islam $\mathrm{KR}$, and Weil RR, 2000). Soil $\mathrm{pH}$ was measured by the standard method of measuring soil $\mathrm{pH}$ with a suspension of 1 part soil by weight to 2.5 distilled water using a glass electrode ( $\mathrm{pH}$ meter) (Karaoz, 1989). Soil organic carbon concentration in the soil samples was determined according to Walkley and Black (1934). Christopher et al. (2017) reviewed a total of 100 publications for which the method used to calculate SOC stocks was recorded and identified four different methods, which vary in use of the parameters BD and rock fragments content. In method one (M1), a certain volume of soil is sampled, dried, and weighed to determine BD. Thereby, no separation into fine soil and coarse soil (rock fragments, roots) fraction is made, while $\mathrm{C}$ concentration is determined in a sieved fine soil sample (usually $<2 \mathrm{~mm}$ ). Soil organic carbon stocks are then calculated as follows:

$$
\begin{aligned}
& \mathrm{M} 1: \mathrm{BD}_{\text {sample }}=\frac{\text { mass of sample }}{\text { volume of sample }} \\
& \mathrm{SOC}_{\text {stock } i}=\mathrm{SOC}_{\text {con }} \text { fine soil } \times, \mathrm{BD}_{\text {sample }} \times \text { depth } i
\end{aligned}
$$

where BD sample is the bulk density of the total sample, a mass sample is the total mass of the sample, volume sample is the total volume of the sample, SOC stocki is the SOC stock of the investigated soil layer (i) (Mg ha-1), SOC confine soil is the content of SOC in the fine soil $(\%)$ and depth $\mathrm{i}$ is the depth of the 


\section{SJIF Impact Factor 2021: 7.13| ISI I.F.Value:1.241| Journal DOI: 10.36713/epra2016 \\ ISSN: 2455-7838(Online) \\ EPRA International Journal of Research and Development (IJRD) \\ Volume: 6 | Issue: 2 | February 2021 \\ - Peer Reviewed Journal}

respective soil layer $(\mathrm{cm})$. This method does not account for rock fragments at all. In method two (M2), a certain volume of soil is sampled, dried, and weighed. However, after sieving, the mass and volume of rock fragments and coarse roots are determined. The equations can be simplified by omitting coarse roots, which is also "common practice", although the volume occupied by roots can be considerably high. By approximating a rock fragments density ( $\rho$ rock fragments) of $2.6 \mathrm{~g} \mathrm{~cm}-3$ Don et al. (2007) (root density is usually assumed to be close to $1 \mathrm{~g} \mathrm{~cm}-3$ ), $\mathrm{BD}$ of the fine soil is subsequently calculated as M2: $\mathrm{BD}$ fine soil $=\frac{\text { Mass sample }- \text { Mass rock fragments }}{\text { Volume sample }-\frac{\text { Mass rock fragments }}{\text { prockfragments }}}$

$\mathrm{SOC}_{\text {stock } i}=\mathrm{SOC}_{\text {con }}$ fine soil $\times \mathrm{BD}_{\text {fine soil }} \times$ depth $i$. (4).

Thus in M2, coarse soil content is accounted for in Eq. (3), not in Eq. (4). The opposite is true for the next method (M3), in which the rock fragments fraction (vol. \%/100), is determined, but only applied to reduce the soil volume (Eq. 5), and not to determine BD fine soil.

M3: Eq. (1), SOC stock $_{i}=$ SOC confine soil $\times$ BD sample $\times$ depth $_{i} \times(1$ - rock fragments fraction) (5). In method four (M4), the coarse soil fraction is accounted for in both equations, i.e. to calculate BD fine soil (Eq. 3) and the volume of the fine soil (Eq. 6)

M4: Eq. (3), SOC stock $_{\mathrm{i}}=$ SOC confine soil $\times$ BD fine soil $\times$ depth $_{\mathrm{i}} \times(1$ - rock fragments fraction $)$ (6). For this research purpose, the first methodology was used as there were no rock fragments in the study area where experimental plots were established.

The factors that affect the rate of decomposition of mulch such as soil moisture were measured and soil characteristics under the experimental plots tested. Soil moisture content was determined by taking a fresh soil sample from depths of $0-20 \mathrm{~cm}$ and $20-40 \mathrm{~cm}$ in the experimental field at the end of the summer barley growing season. Sampled fresh soil was dried, and weighed in the oven for 24 hours at $105 \circ \mathrm{C}$. The gravimetric soil water content was determined using (1) after weighing the oven-dried soil sample (ICARDA, 2013).

Soil moisture (\%)

$=\frac{\text { fresh soil weight-dry soil weight }}{\text { dry soil weight }} \times 100$------------1

The Available Phosphorus ( $\mathrm{P}_{\mathrm{ava}}$ ) content was analyzed using the Olsen method. (1954) also, extractable $\mathrm{K}$ was measured by flame Photometer. The method uses a neutral ammonium acetate solution $(1 \mathrm{~N})$ to replace the cations present on the soil exchange complex.

The organic matter content of soil can be roughly estimated from the total nitrogen content of soil by multiplying the percent total nitrogen by 20 .
This assumes a $5 \% \mathrm{~N}$ in the organic matter of $\mathrm{C}: \mathrm{N}$ ratio of 11:6 since the organic matter is conventionally assumed to contain $58 \%$ carbon. This estimation of the soil organic matter from the nitrogen content may be as accurate as from the carbon content. Percent of total nitrogen $=\%$ organic matter $/ 20$ (Nelson D.W and E.Sommers, 1982).

\subsection{Statistical Analysis}

The first test for normality ('KolmogorovSmirnov') for the properties of the soil was conducted. The ANOVA models were utilized to compare the effect of treatment types and soil depth depending on soil physicochemical properties using the general linear model (Proc GLM with Tukey's HSD) procedures of SAS software (SAS Institute, 2002). Pearson's correlation coefficients were tested for significance using $\mathrm{p}<0.05$ as a criterion for significance. The pairwise comparison method was also used to assess the mean difference among the treatment types and depth levels depending on soil properties.

\section{RESULTS AND DISCUSSIONS}

The result from experimental plots established on farmers' land indicated that yield obtained from current mulch plots was on average higher than a year ago mulched plots, and the least was obtained from conventional farmland plots (Fig 3). The yield levels of CA systems are comparable with and even higher than those under conventional tillage systems Jug et al. (2005), with respect to all principles of sustainable agricultural production (Jug et al., 2017). The principles are reduced use of agrochemicals reflecting on the biological component of soil and water quality Laurent et al. (2011), carbon sequestration rate aid ranging from 0.2 to $1.0 \mathrm{t}$ ha- 1 yr-1 Kertész and Madarász, (2014), depending on the agro-ecological conditions and soil management methods GonzálezSánchez et al. (2017), reducing the workload by $50 \%$, which allows producers to save time, reduce fuel costs and machinery (Lindwall and Sonntag, 2010). The Grand mean of barley grain yield obtained was $1.48 \pm 0.15 \mathrm{~kg}$ from $5 \mathrm{~m}^{2}$ area of each subplot sampled from $200 \mathrm{~m}^{2}$ areas of each main plot. On hectare bases yield obtained from current mulch, a year ago mulch plot and conventional farm plot was $3040 \mathrm{~kg}, 2968 \mathrm{~kg}$, and $2880 \mathrm{~kg}$ respectively (Fig 3).

\subsection{Effect of mulching on soil physical properties in experimental plots \\ 3.1.1 Soil textural class}

The soil textural fractions of sand $(\mathrm{p}=0.0115)$ and clay $(p=0.004)$ showed significant variation with soil depth. The sand fraction was higher in the current mulch plot followed by a year ago mulched plot (Table 1). Overall mean sand fraction was lower under 


\section{SJIF Impact Factor 2021: 7.13| ISI I.F.Value:1.241| Journal DOI: 10.36713/epra2016 \\ ISSN: 2455-7838(Online) \\ EPRA International Journal of Research and Development (IJRD) \\ Volume: 6 | Issue: 2 | February 2021 \\ - Peer Reviewed Journal}

conventional farm plots compared to the other treatment types. On the other hand, conventional farm plots had a higher clay fraction compared to another treatment type. When fine particles of soil are high, increasing electrical conductivity causes the instability of soil structure and might affect the interaction between soil and crop (Tayel et al., 2010). According to Powlson et al. (2011), the interactions between soil and crop are influenced by clay content, temperature and moisture content of the soil, and oxygen availability in the soil. About $63.3 \%$ of surface soil $(0-20 \mathrm{~cm}$ depth) had sandy loam character, while $26.7 \%$ of subsurface soil was sandy clay loam. Clay loam and loam soil had small proportions with about $6.7 \%$ and $3.3 \%$ respectively of subsurface soil. The Pearson correlation coefficient showed that sand fraction was significantly positively correlated with soil organic carbon concentration at $(\mathrm{p}=0.01)$ while, clay fraction was significantly negatively correlated with soil organic carbon concentration and with sand fraction at $(p=0.01)$. Silt fraction was significantly positively correlated with soil organic carbon concentration $(\mathrm{p}=0.05), \quad$ available potassium $(\mathrm{p}=0.01), \quad$ and significantly negatively correlated with clay fraction at $(\mathrm{p}=0.05)$ (Table 2). The strong correlation between silt content and soil organic $\mathrm{C}$ reflects the greater water holding capacity and plant available water of siltdominated soils, which, in turn, affect plant productivity and influence $\mathrm{C}$ sequestration in soil.

\subsubsection{Soil Moisture Content}

There was no significant moisture content variation with the soil depth $(\mathrm{p}=0.0816)$. The results showed that overall mean soil moisture content was slightly higher under current mulch plots while the lowest was observed in conventional farm plots compared with other treatment types. There was significant moisture content variation with the treatment types $(p=0.0095)$. The Pearson correlation coefficient showed that moisture content was significantly positively correlated with clay fraction and bulk density at $(\mathrm{p}=0.01)$ and significantly negatively correlated with available potassium and sand fraction at $(\mathrm{p}=0.05)$ (Table 2$)$.

\subsubsection{Soil Bulk Density}

The treatment types significantly $(p=0.012)$ affected soil bulk density. This argument is in line with Mulumba and Lal, (2008) who reported that the effect of mulching on soil bulk density varies depending on the type and properties of the soil, type of mulch, climate, and land use. Bulk density was higher under conventional farm plots followed by a year ago mulched plot compared to another treatment type. According to Abad et al. (2014); Amanuel et al. (2018) the soils of agricultural land had the highest bulk densities in comparison to other land-use types. Soil bulk density didn't show a significant difference with the soil depth $(\mathrm{p}=0.089)$. The lower soil bulk density under current mulch plots could be related to the higher organic matter content which increases the soil volume without affecting its weight and higher bulk density in conventional farm plots could be attributed to the impact of repeated tillage which disturbs the soil structure, causing a compacted surface soil layer. Yimer and Abdurkadir. (2011) reported that the application of organic materials from the plant system leads to a decrease in the surface soil bulk density than the layer below. Yimer et al. (2006) also indicated that the compaction resulting from the weight of the top layer might be the reason for the increased bulk density in the lower layer. The Pearson correlation coefficient showed that bulk density was significantly positively correlated with clay fraction at $(\mathrm{p}=0.01)$ and significantly negatively correlated with soil organic carbon concentration, and with sand fraction at $(\mathrm{p}=0.01)$ and with available potassium at $(\mathrm{p}=0.05)$ (Table 2).

\subsection{Effect of mulching on soil chemical properties in experimental plots}

\subsubsection{Soil pH}

There was no significant difference in soil $\mathrm{pH}$ with soil depth $(\mathrm{p}=0.786)$ and all the treatment types. The results indicated that the mean soil $\mathrm{pH}$ was 5.987 and ranged from 5.07 to 6.67 across the treatment types. Results showed that the overall mean soil $\mathrm{pH}$ was higher under the current mulch plot and lower under conventional farm plots compared to another treatment type. The lowest soil $\mathrm{pH}$ was recorded under conventional farm plots while the highest soil $\mathrm{pH}$ was recorded under current mulch plots of soil depth 20$40 \mathrm{~cm}$ in both cases (Table 3 ).

It was found that soil acidity was higher in conventional farm plots which might be related to the addition of a high rate of inorganic fertilizer compared to current mulch and a year ago mulched plots. The higher acidity (lower $\mathrm{pH}$ ) in cultivated land compared with forest land was probably due to continuous removal of basic cat-ions by crops, crops' harvest enhanced leaching of basic cat-ions and washed away of exchangeable bases by soil erosion( Amanuel et al.,2018).

\subsubsection{Soil organic carbon concentration}

The soil organic carbon concentration showed a significant difference with soil depth $(\mathrm{p}<0.0001)$. The mean SOC concentration was higher under the current mulch plot and lower in soil under the conventional farm plot than other treatment types in the $0-20 \mathrm{~cm}$ and $20-40 \mathrm{~cm}$ soil depth, respectively (Table 3 ). This result is consistent with Amanuel et al.( 2018) who reported 


\section{SJIF Impact Factor 2021: 7.13| ISI I.F.Value:1.241| Journal DOI: 10.36713/epra2016 \\ ISSN: 2455-7838(Online) \\ EPRA International Journal of Research and Development (IJRD) \\ Volume: 6 | Issue: 2 | February 2021 \\ - Peer Reviewed Journal}

that the lower SOC concentration found in the deeper layer could be related to the reduced amount of the external inputs into the soil, and animal wastes and inorganic fertilizers temporarily remain in the top surface soil rather than going deeper (Alemayehu et al.,2010). The soil organic carbon concentration also showed a significant difference with treatment types $(p=0.0004)$. The overall mean SOC concentration was higher under the current mulch plot and followed by a year ago mulch plot while conventional farm plot has lower overall mean SOC concentration compared to the other treatment type. According to Manu et al. (2014) a marked decline in soil C, wet aggregate stability, and nutrient status occurred as land use changed from forest to cropping and has suggested that the addition of mulches could be a way to arrest this decline in the resource base. Under cereal land cultivation, the low SOC content may be due to frequent harvesting by crops which thereby perpetually remove the nutrients from the soil (Fermont et al. 2008; Haileslassie et al. 2005). Generally, it has a decreasing trend with soil depth.

\subsubsection{Total Nitrogen}

The available Nitrogen showed a significant difference with soil depth $(p<0.0001)$. The mean available Nitrogen was higher under the current mulch plot and lower in soil under the conventional farm plot than other treatment types in the $0-20 \mathrm{~cm}$ and $20-40 \mathrm{~cm}$ soil depth, respectively (Table 3 ). The available Nitrogen also showed a significant difference with treatment types $(\mathrm{p}=0.0004)$. The overall mean available Nitrogen was higher under the current mulch plot and followed by a year ago mulch plot while conventional farm plot has lower overall mean available Nitrogen compared to the other treatment type. According to Abadi et al. (2014), the highest value of total nitrogen was observed for forests and significantly differs from pasture land and cultivated land. Generally, it has a decreasing trend with soil depth.

\subsubsection{Available potassium (K)}

There was no significant difference of available potassium $(\mathrm{K})$ with soil depth $(\mathrm{p}=0.076)$ and all the treatment types $(\mathrm{p}=0.086)$. The mean available potassium (K) was higher under a year ago mulch plot and lower in soil under conventional farm plot than other treatment types in the $0-20 \mathrm{~cm}$ and $20-40 \mathrm{~cm}$ soil depth, respectively(Table 3). The overall mean available potassium $(\mathrm{K})$ was found to be higher under the current mulch plot and lower in soils under conventional farm plots than another treatment type. According to Abadi et al. (2014), the highest value of available potassium was observed for forests and significantly differs from pasture land and cultivated land. The Pearson correlation coefficient showed that available potassium was significantly positively correlated with soil organic carbon concentration at $(\mathrm{p}=0.05)$ (Table 2).

\subsubsection{Available phosphorus (P)}

There was no significant difference of available phosphorus $(\mathrm{P})$ with soil depth $(\mathrm{p}=0.188)$ and all the treatment types $(p=0.753)$. The mean available phosphorus $(\mathrm{P})$ was higher under the current mulch plot and lower in soil under a year ago mulch plot than another treatment type in the $0-20 \mathrm{~cm}$ and $20-40 \mathrm{~cm}$ soil depth, respectively (Table 3). The overall mean available phosphorus $(\mathrm{P})$ was found to be higher under the current mulch plot and lower in soils under a year ago mulch plots than another treatment type. The Pearson correlation coefficient showed that available phosphorus was significantly positively correlated with soil organic carbon concentration at $(\mathrm{p}=0.05)$ (Table 2$)$.

\subsubsection{Soil organic carbon stock}

The result showed that mean SOC stock was highly influenced by soil depth $(\mathrm{p}<0.0001)$. The mean SOC stock was higher under the current mulch plot and lower in soil under the conventional farm plot than other treatment types in the $0-20 \mathrm{~cm}$ and $20-40 \mathrm{~cm}$ soil depth, respectively (Table 3 ). The overall mean SOC stock was found to be higher under the current mulch plot and lower in soils under conventional farm plots than another treatment type. Worldwide, CA has been promoted as a strategy to enhance soil fertility, increase soil organic C (SOC), and reduce greenhouse gas emissions Derpsch et al. (2010) besides reducing production costs (Johansen et al. 2012). The Pearson correlation coefficient showed that soil organic carbon stock was significantly positively correlated with available Phosphorus $(\mathrm{p}=0.01)$ and a sand fraction $(\mathrm{p}=0.05)$ and significantly inversely correlated with clay fraction $(\mathrm{p}=0.01)($ Table 2$)$.

\section{CONCLUSIONS AND RECOMMENDATIONS}

\subsection{Conclusions}

In general, the highest overall mean of carbon concentration and stock under current mulch indicates that integration of perennial mulching with other modern agricultural technologies and packages might be the remedy for replenishing the declining soil fertility on conventional farmlands to increase barley grain yield on a sustainable basis. The absence of addition of organic matter from perennial crops and removal of the crop residues from cultivated land during crop harvesting and continuous tillage practice might be the reason for lower soil carbon and nutrients on conventional farmlands as well as for subsequent low barley grain yield. 


\section{SJIF Impact Factor 2021: 7.13| ISI I.F.Value:1.241| Journal DOI: 10.36713/epra2016 \\ ISSN: 2455-7838(Online) \\ EPRA International Journal of Research and Development (IJRD) \\ Volume: 6 | Issue: 2 | February 2021 \\ - Peer Reviewed Journal}

Farmers mulched with Rosa abyssinica to get high barley grain yield with low external input, for its moisture retention capacity, nutrient conservation, zero erosion, and higher carbon content, which made it preferable climate-smart technology for smallholder farmers in the study area.

\subsection{Recommendation}

Integration of indigenous knowledge of perennial mulching with modern scientific technology should be considered in agricultural technology dissemination through agricultural extension, to promote conservation agriculture to the wider public. Different agronomic practices that boost total nitrogen, soil organic carbon, available phosphorus, and potassium in the system should be considered when the land is intensively cultivated.

The practice of mulching with Rosa abyssinica was reduced in the study area in the past decade, because of the reduction of mulching materials that resulted from various anthropogenic factors. Consequently, shrinking of landholding size of farmers was happened; so that mulching with ex-situ grown Rosa abyssinica and future research on alley cropping by introducing it to conventional farmland and ensuring clear land tenure and as well as the creation of many other livelihood alternatives for youth is suggested solutions so as to ensure the sustainability of the practice of mulching with Rosa abyssinica in the study area.

\section{Acknowledgments}

The first author is grateful to Ethiopian Environment and Forest Research Institute and the national MRV capacity building center for providing me financial supports. I am also grateful to Wondogenet College of Forestry and Natural Resource soil laboratory technicians for their technical support during soil analysis.

\section{Funding}

This study was financial supported by the Ethiopian Environment and Forest Research Institute and the national MRV capacity building center of Hawassa University, Wondogenet College of Forestry and Natural Resources.

\section{Authors' Contributions}

Both authors contributed to the study conception and design. The first author wrote the manuscript, collected, and analyzed the data. The second author Commented on previous versions of the manuscript participated in the design of the study and examined the manuscript. Both authors read and approved the final manuscript. Ethics approval and consent to participate

Not applicable

Consent for publication

Not applicable
Competing interests

The authors declare that they have no competing interests.

\section{REFERENCES}

1. Abad J Rafi, Hassan Khosravi and Esmaeil Haidari Alamdarlou .2014. Assessment of the effects of land-use changes on soil physicochemical properties in Jafarabad of Golestan province, Iran. Bull. Env. Pharmacol. Life Sci., Vol 3 p: 296-300

2. Alemayehu, L., Hager, H., \& Sieghardt, M. (2010). Effect of land-use types on soil chemical properties in smallholder farmers of central highland Ethiopia. Ekologia (Bratislava), 29(1), 1-14.

3. Amanuel W, Yimer F, and Karlton E.2018. Soil organic carbon variation in relation to land-use changes: the case of Birr watershed, upper Blue Nile River Basin, Ethiopia. Journal of Ecology and Environment, 42:16

4. Bekele-Tesemma, A. 2007. Useful trees of Ethiopia: identification, propagation, and management in 17 agro-ecological zones. Nairobi: RELMA in ICRAF Project, 552p.

5. Chapman, S.K., Palanivel, R.U., Langley, J.A., 2012. Soil carbon stability responds to land use and groundcover management in the southern Appalachian agroecosystems. Soil Sci. Soc. Am. J. 76, 2221-2229.

6. Christopher Poeplau, Cora Vos, and Axel Don.2017. Soil organic carbon stocks are systematically overestimated by misuse of the parameters bulk density and rock fragment content. Thünen Institute of Climate-Smart Agriculture, Braunschweig, Germany. Soil, 3, 61-66

7. De Ridder N, Breman H, van Keulen H, Stomph TJ 2004. Revisiting a 'cure against land hunger': soil fertility management and farming systems dynamics in the West African Sahel. Agric Syst 80(2):109131.

8. Derpsch, R., Friedrich, T., Kassam, A., \& Hongwen, L. (2010). Current status of adoption of no-till farming in the world and some of its main benefits. International Journal of Agriculture and Biological Engineering, 3(1), 1-25.

9. Don, A., Schumacher, J., Scherer-Lorenzen, M., Scholten, T., and Schulze, E. D.2007. Spatial and vertical variation of soil carbon at two grassland sites - Implications for measuring soil carbon stocks, Geoderma, 141, 272-282

10. Dossa EL, Diedhiou I, Khouma M, SeneM, Badiane AN, Ndiaye Samba SA, Assigbetse KB, Sall $S$, Lufafa A, Kizito F, Dick RP, Saxena J .2013.Crop productivity and nutrient dynamics in a shrubbased farming system of the Sahel. Agron J 105(4):1237.

11. Félix GF, Clermont-Dauphin C, Hien E, Groot JCJ, Peniche A, Barthès BG, Manley RJ, Tittonell P, Cournac L .2018. Ramial wood amendments (Piliostigma reticulatum) mitigate the degradation 


\section{SJIF Impact Factor 2021: 7.13| ISI I.F.Value:1.241| Journal DOI: 10.36713/epra2016 \\ ISSN: 2455-7838(Online) EPRA International Journal of Research and Development (IJRD) Volume: 6 | Issue: 2 | February 2021 - Peer Reviewed Journal}

of tropical soils but do not replenish nutrient exports. Land Degradation and Development 29(8):2694-2706.

12. Fermont, A. M., van Asten, P. J. A. ., \& Giller, K. E. (2008). Increasing land pressure in East Africa: the changing role of cassava and consequences for the sustainability of farming systems. Agriculture, Ecosystems, and Environment, 128, 239-250.

13. Giller, K. E., Witter E., Corbeels M., Tittonell P. 2009. "Conservation agriculture and smallholder farming in Africa: The heretics' view." Field Crops Research.114, 23-34.

14. González-Sánchez, E.J., Moreno-García, M., Kassam, A., Holgado-Cabrera, A., TriviñoTarradas, P., Carbonell- Bojollo, R., Pisante, M., Veroz-González, O. \& Basch, G. (2017). Conservation Agriculture: Making Climate Change Mitigation and Adaptation Real in Europe. ECAF, Brussel http: //www.ecaf.org /inaction/ news/ item/60- a-major-new-research-study-in favor-of conservation agriculture (16.03.18)

15. Haileslassie, A., Priess, J., Veldkamp, E., Teketay, D., \& Lesschen, J. P. (2005). Assessment of soil nutrient depletion and its spatial variability on smallholders' mixed farming systems in Ethiopia using partial versus full nutrient balances. Agriculture, Ecosystems, and Environment, 108, 116.

16. ICARDA. 2013. Methods of soil, plants, and water analysis: A manual for West Asia and North Africa regions. International Center for Agricultural Research in the Dry Areas (ICARDA), Beirut, Lebanon.

17. Islam KR, Weil RR. (2000). Land-use effects on soil quality in a tropical forest ecosystem of Bangladesh. Agriculture, Ecosystems \& Environment 79, 9-16.

18. Jug, D., Blažinkov, M., Redžepović, S., Jug, I. \& Stipešević, B. (2005). Effects of different soil tillage systems on nodulation and yield of soybean. $\begin{array}{llll}\text { Poljoprivreda, } & 11 & \text { (2), }\end{array}$ https://hrcak.srce.hr/11943

19. Jug D., Jug I., Vukadinović V., Đurđević B., Stipešević B. \& Brozović B. (2017). Conservation soil tillage as a measure for climate change mitigation. University textbook (In Croatian). Croatian Soil Tillage Research Organization, Osijek, Croatia. ISBN: 978-953-7871-61-1.

20. Kader, M.A., Senge, M., Majid, M.A., \&Ito, K.2017.Recent advances in mulching materials and methods for modifying the soil environment. Soil and Tillage Research, 168, 155-166.

21. Karaoz, O. (1989). Analyze methods of some chemical soil properties ( $\mathrm{pH}$, carbonates, salinity, organic matter, total nitrogen, and available phosphorus). Review of the Faculty of Forestry, University of Istanbul, 39(B3), 64-82 Istanbul, Turkish.
22. Kertész, Á. \& Madarász, B. (2014). Conservation Agriculture in Europe. International Soil and Water Conservation Research, 2(1), 91-96. https://doi. org/10.1016/S2095-6339 (15)30016-2

23. Laurent, F., Leturcq, G., Mello, I., Corbonnois, J. \& Verdum, R. (2011). La diffusion du semis direct au Brésil, diversité des pratiques et logiques territoriales: l'exemple de la région d'Itaipu au Paraná. https://doi. org/10.4000/confins. 7143

24. Lindwall, C. W. \& Sonntag, B. (2010). Landscape Transformed: The History of Conservation Tillage and Direct Seeding, Knowledge Impact in Society, Saskatoon, University of Saskatchewan.

25. Manu, V., Whitbread, A., Blair, N. \& Blair, G. 2014. Carbon status and structural stability of soils from differing land-use systems in the Kingdom of Tonga. Soil Use and Management, 30, 517-523.

26. Мапи V., Whitbread, A. \& Blair G.2018. Effects of vegetative mulches on the growth of indigenous crops in the Kingdom of Tonga. British Society of Soil Science, Soil Use and Management

27. McMillen, M., 2013. The Effect of Mulch Type and Thickness on the Soil Surface Evaporation Rate. California Polytechnic State University, USA.

28. Mulumba, L.N., Lal, R., 2008. Mulching effects on selected soil physical properties. Soil Tillage Res. 98, 106-111.

29. Nelson D.W and L.E. Sommers.1982.Total carbon, organic carbon, and organic matter. in page et al. Methods of soil analysis part 2: chemical and microbiological properties.539-79pp.second Edition. A.S.A Madison Wisconsin USA.

30. Olsen, S.R., V.Cole, F.S, Watanabe, and L.A.Dean.1954.Estimation of available phosphorus in soils by extraction with sodium bicarbonate.USDA Cir.No.939.

31. ORS, 2004. Socio-economic profile of East Shoa Zone. The Oromia Regional State Government, Ethiopia.

32. Powlson, D.S., Gregory, P.J., Whalley, W.R., Quinton, J.N., Hopkins, D.W., Whitmore, A.P., Hirsch, P.R., Goulding, K.W.T., 2011. Soil management in relation to sustainable agriculture and ecosystem services. Food Policy, 36, 72-87.

33. Qian, X., Gu, J., Pan, H., et al., 2015. Effects of living mulches on the soil nutrient contents, enzyme activities, and bacterial community diversities of apple orchard soils. Eur. J. Soil Biol. 70, 23-30. https:// doi.org/ 10.1016/j. Jacobi. 2015. 06.005.

34. SAS Institute, (2002). The SAS system for Microsoft Windows. Release 9.0, Cary, NC, USA.

35. Sharma, A.R.and Behere, U.K.2010.Green leaf manuring with the pruning of Leucaena Leucocephala for nitrogen economy and improved productivity of maize (Zea mays)-wheat (Triticum aestivum) cropping system. Nutrient cycling in agro ecosystem.86:39-5

36. Silvertown, J., Poulton P, Johnston E, Edwards G, Heard M, Biss PM. 2006. "The Park Grass 
Experiment 1856-2006: It's a contribution to ecology." J. Ecol. 94(4): 801-814.

37. Steinmetz, Z., Wollmann, C., Schaefer, M., Buchmann, C., David, J., Tröger, J., Muñoz, K., Frör, O., Schaumann, G.E., 2016. Plastic mulching in agriculture. Trading short-term agronomic benefits for long-term soil degradation? Sci. Total Environ. 550, 690-705.

38. Tayel MY, Abdel-Hady M, Eldardiry EI. (2010). Soil structure affected by some soil characteristics. American- Eurasian Journal of Agriculture \& Environmental Science 7(6), 705-712.

39. Wang, Z., Zhao, X., Wu, P., \& Chen, X.2015.Effects of water limitation on yield advantage and water use in wheat (TriticumaestivumL.) maize (ZeamaysL.) strip intercropping. European Journal of Agronomy, 71, 149-159.

40. Walkley, A., \& Black, C. A. (1934). An examination of the Degtjareff method for determining soil organic matter and proposed modification of the chromic acid titration method. Soil Science, 37, 29_ 38 .

41. Yimer F., Ledin, S., \& Abdu, A. (2006). Soil property variations in relation to topographic aspect and vegetation community in the southeastern highlands of Ethiopia. Forest Ecology and Management, 232, 90-99.

42. Yimer F., \& Abdurkadir, A. (2011). Soil property change following the conversion of acacia woodland into grazing and farmlands in the Rift Valley area of Ethiopia. Land Degradation and Development, 22, 425-431.

43. Zhong Z, Huang X, Feng D, Xing S, Weng B.2018. Long-term effects of legume mulching on soil chemical properties and bacterial community composition and structure. Agriculture, Ecosystems and Environment .268:24-33 


\section{APPENDIX}

\section{LIST OF FIGURES}

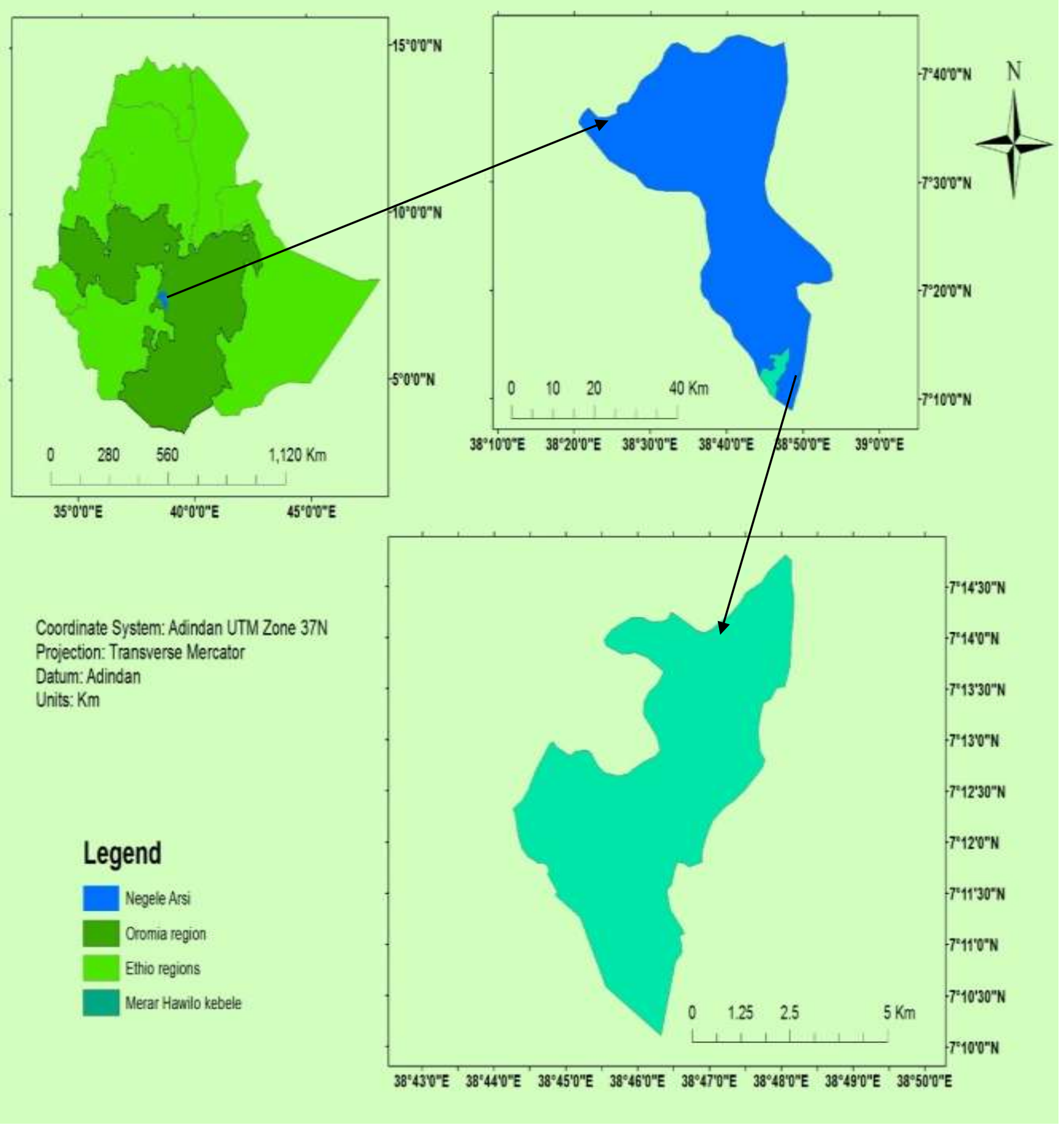

Fig 1: Location Map of Meraro Hawilo kebele located between $7^{\circ} 10^{\prime} 0^{\prime \prime}-7^{\circ} 14^{\prime} 30 " \mathrm{~N}$, and $38^{\circ} 43^{\prime} 0^{\prime \prime}-$ $38^{\circ} 50^{\prime} 0 " \mathrm{E}$. 


\section{$20 \mathrm{~m}$}

(a)

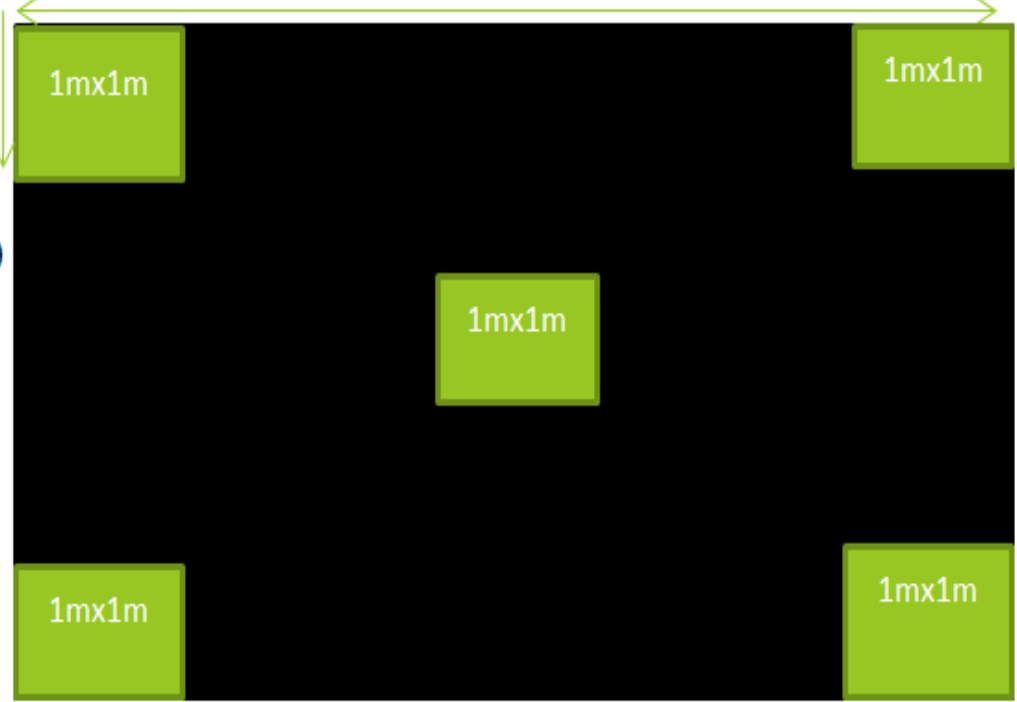

$10 \mathrm{~m}$

(c)

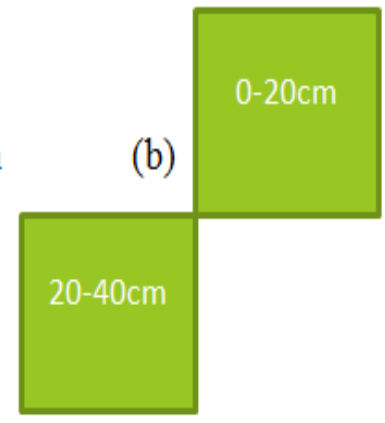

Fig 2: Field plots establishment procedure for barley and soil physiochemical properties (at depth of $0-20 \mathrm{~cm}$ and $20-40 \mathrm{~cm}$ ) measurement

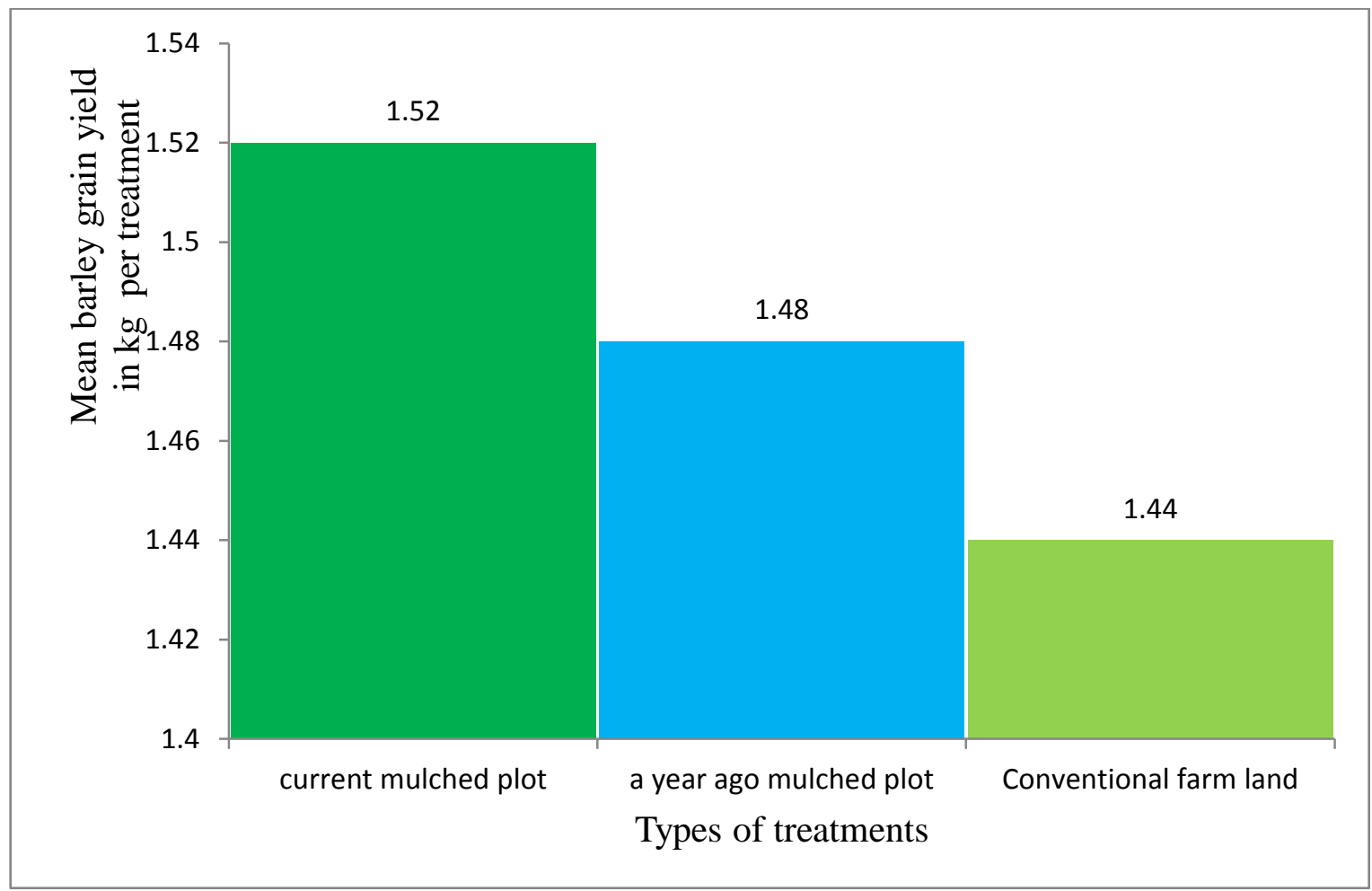

Fig 3: Mean yield in kilogram per treatment of conservation agriculture verses conventional farm land from experimental plots 


\section{LIST OF TABLES}

Table 1: Mean (( \pm standard deviation) of the soil physical properties across the treatments $(0-40 \mathrm{~cm})$

\begin{tabular}{|c|c|c|c|c|c|}
\hline \multirow{2}{*}{$\begin{array}{l}\text { Response } \\
\text { variable }\end{array}$} & \multirow{2}{*}{$\begin{array}{c}\text { Soil } \\
\text { depth } \\
\text { (cm) }\end{array}$} & \multicolumn{3}{|c|}{ Treatments } & \multirow[t]{2}{*}{ overall } \\
\hline & & $\begin{array}{c}\text { Current mulch } \\
\text { plot }\end{array}$ & $\begin{array}{c}\text { Year ago } \\
\text { mulched plot }\end{array}$ & $\begin{array}{c}\text { Conventional } \\
\text { farm plot }\end{array}$ & \\
\hline \multirow[t]{3}{*}{ Sand $\%$} & $0-20$ & $63.6 \mathrm{a} \pm 3.85$ & $59.6 \mathrm{ba} \pm 5.37$ & $59.6 \mathrm{ba} \pm 3.85$ & $60.93 \pm 4.53$ \\
\hline & $20-40$ & $59.6 \mathrm{ba} \pm 5.18$ & $54.8 \mathrm{bc} \pm 5.40$ & $49.6 c \pm 8.99$ & $54.67 \pm 7.55$ \\
\hline & Overall & $61.6 \mathrm{a} \pm 4.79$ & $57.2 \mathrm{a} \pm 5.67$ & $54.6 \mathrm{a} \pm 8.38$ & \\
\hline \multirow[t]{3}{*}{ Clay \% } & $0-20$ & $12.0 \mathrm{c} \pm 2.83$ & $10.8 \mathrm{c} \pm 2.28$ & $16.0 \mathrm{bc} \pm 3.16$ & $12.93 \pm 3.45$ \\
\hline & $20-40$ & $16.4 b c \pm 5.18$ & $22.0 \mathrm{ba} \pm 6.78$ & $26.0 \mathrm{a} \pm 9.06$ & $21.47 \pm 7.80$ \\
\hline & Overall & $14.2 \mathrm{a} \pm 4.57$ & $16.4 \mathrm{a} \pm 7.59$ & $21.0 \mathrm{a} \pm 8.29$ & \\
\hline \multirow[t]{3}{*}{ Silt \% } & $0-20$ & $24.4 \mathrm{~b} \pm 1.67$ & $29.6 a \pm 3.85$ & $24.4 \mathrm{~b} \pm 3.29$ & $26.13 \pm 3.82$ \\
\hline & $20-40$ & $24.0 \mathrm{~b} \pm 6.00$ & $23.2 \mathrm{~b} \pm 1.79$ & $24.4 \mathrm{~b} \pm 3.58$ & $23.87 \pm 3.89$ \\
\hline & Overall & $24.2 \mathrm{a} \pm 4.16$ & $26.4 \mathrm{a} \pm 4.40$ & $24.4 \mathrm{a} \pm 3.24$ & \\
\hline \multirow[t]{3}{*}{$\mathrm{BD}\left(\mathrm{g} / \mathrm{cm}^{3}\right)$} & $0-20$ & $0.44 \mathrm{~b} \pm 0.05$ & $0.468 \mathrm{ba} \pm 0.13$ & $0.57 \mathrm{ba} \pm 0.11$ & $0.49 \pm 0.11$ \\
\hline & $20-40$ & $0.48 \mathrm{ba} \pm 0.04$ & $0.55 b a \pm 0.17$ & $0.59 \mathrm{a} \pm 0.07$ & $0.55 \pm 0.11$ \\
\hline & Overall & $0.46 \mathrm{a} \pm 0.05$ & $0.51 \mathrm{ba} \pm 0.15$ & $0.58 \mathrm{~b} \pm 0.08$ & \\
\hline \multirow[t]{3}{*}{ MC\% } & $0-20$ & $20.04 b \pm 1.71$ & $18.08 \mathrm{~b} \pm 2.56$ & $17.59 b \pm 1.35$ & $18.57 \pm 2.11$ \\
\hline & $20-40$ & $20.86 b a \pm 0.62$ & $19.31 \mathrm{ba} \pm 2.98$ & $18.69 \mathrm{ba} \pm 1.07$ & $19.62 \pm 1.97$ \\
\hline & Overall & $20.45 b \pm 1.29$ & $18.69 \mathrm{ba} \pm 2.69$ & $18.15 \mathrm{a} \pm 1.29$ & \\
\hline
\end{tabular}

The mean values followed by the different letters across rows are significantly different $(\mathrm{p}<0.05)$

Table 2: Pearson correlation matrix for soil physiochemical properties $(0-40 \mathrm{~cm})$

\begin{tabular}{|c|c|c|c|c|c|c|c|c|c|}
\hline & $\% 0 \mathrm{OC}$ & $\mathrm{k}(\mathrm{ppm})$ & $\mathrm{p}(\mathrm{ppm})$ & $\mathrm{pH}$ & $\%$ sand & $\%$ clay & $\%$ silt & $\mathrm{BD}$ & MC\% \\
\hline$\% O C$ & 1 & & & & & & & & \\
\hline $\mathrm{k}(\mathrm{ppm})$ & $0.385^{*}$ & 1 & & & & & & & \\
\hline $\mathrm{p}(\mathrm{ppm})$ & $0.437^{*}$ & 0.081 & 1 & & & & & & \\
\hline $\mathrm{pH}$ & 0.339 & 0.234 & -0.079 & 1 & & & & & \\
\hline$\%$ sand & $0.569^{* *}$ & 0.042 & 0.116 & 0.049 & 1 & & & & \\
\hline$\%$ clay & $-0.734^{* *}$ & -0.294 & -0.298 & -0.126 & $-.847^{* *}$ & 1 & & & \\
\hline$\%$ silt & $0.371^{*}$ & $0.473^{* *}$ & 0.351 & 0.148 & -0.169 & $-0.380^{*}$ & 1 & & \\
\hline $\begin{array}{l}\text { Bulk } \\
\text { density }\end{array}$ & $-0.511^{* *}$ & $-0.420^{*}$ & 0.069 & -0.29 & $-0.514^{* *}$ & $0.557^{* *}$ & -0.14 & 1 & \\
\hline MC\% & $-.489^{* *}$ & $-0.430^{*}$ & 0.08 & -0.269 & $-0.444^{*}$ & $0.488^{* *}$ & -0.133 & $0.961^{* *}$ & 1 \\
\hline
\end{tabular}


Table 3: Mean ( $( \pm$ standard deviation) of the soil chemical properties across the treatments $(0-40 \mathrm{~cm})$

\begin{tabular}{llllll}
\hline $\begin{array}{l}\text { Response } \\
\text { variable }\end{array}$ & $\begin{array}{l}\text { Soil } \\
\text { depth } \\
\text { (cm) }\end{array}$ & $\begin{array}{l}\text { Current mulch } \\
\text { plot }\end{array}$ & $\begin{array}{l}\text { Year ago } \\
\text { mulched plot }\end{array}$ & $\begin{array}{l}\text { Conventional } \\
\text { farm land plot }\end{array}$ & overall \\
\hline OC\% & $0-20$ & $6.74 \mathrm{a} \pm 1.057$ & $5.76 \mathrm{a} \pm 0.89$ & $4.39 \mathrm{~b} \pm 0.65$ & $5.63 \pm 1.29$ \\
& $20-40$ & $4.09 \mathrm{bc} \pm 1.62$ & $2.88 \mathrm{~cd} \pm 0.69$ & $2.40 \mathrm{~d} \pm 0.32$ & $3.12 \pm 1.20$ \\
& overall & $5.41 \mathrm{a} \pm 1.90$ & $4.32 \mathrm{ab} \pm 1.69$ & $3.39 \mathrm{~b} \pm 1.15$ & \\
K(PPM) & $0-20$ & $368.60 \mathrm{a} \pm 276.82$ & $396.00 \mathrm{a} \pm 156.36$ & $167.40 \mathrm{a} \pm 145.99$ & $310.67 \pm 214.71$ \\
& $20-40$ & $263.40 \mathrm{a} \pm 187.04$ & $190.00 \mathrm{a} \pm 169.11$ & $165.80 \mathrm{a} \pm 179.92$ & $206.40 \pm 171.06$ \\
& overall & $316.00 \mathrm{a} \pm 229.52$ & $293.00 \mathrm{a} \pm 188.05$ & $166.60 \mathrm{a} \pm 154.47$ & \\
$\mathrm{P}(\mathrm{PPM})$ & $0-20$ & $5.70 \mathrm{a} \pm 1.77$ & $4.75 \mathrm{a} \pm 1.35$ & $5.57 \mathrm{a} \pm 3.69$ & $5.34 \pm 2.35$ \\
& $20-40$ & $4.43 \mathrm{a} \pm 6.49$ & $2.87 \mathrm{a} \pm 3.02$ & $3.21 \mathrm{a} \pm 1.99$ & $3.50 \pm 4.03$ \\
$\mathrm{TN} \%$ & overall & $5.06 \mathrm{a} \pm 4.53$ & $3.81 \mathrm{a} \pm 2.42$ & $4.39 \mathrm{a} \pm 3.06$ & \\
& $0-20$ & $0.58 \mathrm{a} \pm 0.09$ & $0.49 \mathrm{a} \pm 0.07$ & $0.38 \mathrm{~b} \pm 0.06$ & $0.49 \pm 0.11$ \\
& $20-40$ & $0.35 \mathrm{bc} \pm 0.14$ & $0.25 \mathrm{~cd} \pm 0.06$ & $0.21 \mathrm{~d} \pm 0.03$ & $0.27 \pm 0.10$ \\
$\mathrm{pH}$ & overall & $0.47 \mathrm{a} \pm 0.16$ & $0.37 \mathrm{ab} \pm 0.15$ & $0.29 \mathrm{~b} \pm 0.09$ & \\
& $0-20$ & $6.08 \mathrm{a} \pm 0.42$ & $6.01 \mathrm{a} \pm 0.24$ & $5.91 \mathrm{a} \pm 0.10$ & $6.00 \pm 0.27$ \\
& $20-40$ & $6.18 \mathrm{a} \pm 0.36$ & $5.91 \mathrm{a} \pm 0.28$ & $5.82 \mathrm{a} \pm 0.48$ & $5.97 \pm 0.39$ \\
SOC(mg/ha) & $0-20$ & $59.54 \mathrm{a} \pm 12.61$ & $52.32 \mathrm{ba} \pm 6.74$ & $49.64 \mathrm{ba} \pm 11.05$ & $53.83 \pm 10.59$ \\
& & & & & \\
& $20-40$ & $40.12 \mathrm{bc} \pm 18.13$ & $30.27 \mathrm{c} \pm 3.95$ & $28.59 \mathrm{c} \pm 3.49$ & $32.99 \pm 11.38$ \\
& overall & $49.83 \mathrm{a} \pm 17.93$ & $41.29 \mathrm{a} \pm 12.74$ & $39.12 \mathrm{a} \pm 13.52$ & \\
\hline
\end{tabular}

The mean values followed by the different letters across rows are significantly different $(\mathrm{p}<0.05)$ 